\title{
Performance of wheat yield under different fertilizer types, application and doses at Northern Sudan State
}

\author{
Sami Abdel Ghfar Mahgoub ${ }^{1}$ and Yassin Mohammed Ibrahim ${ }^{2}$
}

${ }^{1}$ Department of Agronomy, College of Agric. Sciences, University of Dongola, Sudan. ${ }^{2}$ Professor of Agronomy, College of Agric. Studies, Sudan University of Science and Technology, Sudan.

\begin{abstract}
The experiment was conducted during the successive seasons of 2008/2009 and 2009/2010 at the Demonstration Farm of the Faculty of Agricultural Sciences, University of Dongola, Northern State, Sudan. $\quad$ The aim of this experiment was to study the effect of fertilizer doses, types and application methods on the grain yield of wheat (Triticum aestivum L.). Experimental method is a split-split plot trial with four replications. The main plot was composed of tow methods of fertilizer application (broadcasting and localized placement) in randomized complete block design. Subplots consisted of tow types of compound fertilizers (Urea + Triple super phosphate) and Nitrophoska. Sub-subplots consisted of four doses of each fertilizer. Yield components of wheat which were investigated in this study included number of grains per spike, thousand grains weight, spike index, grain yield and harvest index. In this study the general trend was that the increase in fertilizer dose highly significant increased number of grains per spike in the second season, grain yield in both seasons, but there were no significant difference in thousand grains weight and spike index which were not affected. The results showed that the fertilizer doses significantly decreased harvest index. Generally the results show that there were no significant differences in yield components between the fertilizer types and between the application methods.
\end{abstract}

Keywords: fertilizer, dose, type, method, Yield Components.

\section{INTRODUCTION}

Wheat production in the Sudan started thousands of years ago on the fertile soils of the banks of the Nile in the Northern and Nile River States. Attempts to extend the crop to the central irrigated plains south of Khartoum were made in 1918 and 1940 (Ageeb, 1993). Wheat is Sudan's second most important cereal in terms of consumption, as the present annual consumption requirement for wheat is estimated at more than 1.5 million tones, the import requirement is estimated at about 1.26 million tones (FAO, 2001).

Sudan is one of the developing countries, which suffers from wheat shortage. The shortage is created by the big gap between production and consumption. Besides the environmental conditions, the low yield of wheat in the Sudan is mainly due to low crop stand, untimely sowing, inadequate fertilizer use, poor water management and delayed harvests (Ageeb, 1993).

Experiments in fertilization started since 1925 while commercial use began 1950, where Ammonium sulphate was used as a source of $\mathrm{N}$. Urea as a source of nitrogen dominated since the 1960s. In the 1980 s the use of triple super phosphate was introduced as a source of phosphate. This was followed late (mid 90s) by the use of complex or compound fertilizers, solid or in liquid form (Dawelbeit, et al. 2007).

The main objective of this experiment was to study the effect of fertilizer doses, types and application methods on the grain yield of wheat.

\section{MATERIALS AND METHODS}

The experiment was conducted during the successive seasons of 2008/2009 and 2009/2010 at the Farm of the Faculty of Agricultural Sciences, University of Dongola, Northern State, Sudan, located within latitude $19^{\mathrm{O}_{11}} 1^{\prime} \mathrm{N}$, and longitude $30^{\mathrm{O}} 29^{\prime} \mathrm{E}$ and altitude $227 \mathrm{~m}$.

The Northern State occupies the distant Northern part of the republic of Sudan and lies between 
latitudes $16^{\circ}-22^{\circ} \mathrm{N}$ and longitudes $20^{\circ}-32^{\circ} \mathrm{E}$. The state was cited within the desert region of the Sudan with extremely high temperature and radiation in summer, low temperature in winter, scarce rainfall and high wind speed. The climate is hyper arid with a vapor pressure of only $10.8 \mathrm{mb}$ and a relative humidity of less than $20 \%$ with a mean bright sun shine duration of 10.5 hours (at $87 \%$ of the possible hours). Clouds are generally rare. Solar radiation is as high as 25.88 MJM in May. In general in Dongola the soil area is divided into two main groups, namely soils of the recent flood plain and soils of the high terrace.

The soil of the experimental site (classified as high terrace (aridisols)) was alkaline soil with high content of $\mathrm{Ca} \mathrm{CO}_{3}$. The soil texture characterized as sandy loam with $72 \%$ Sand, $11 \%$ Silt and $17 \%$ Clay.

The experimental area was tilled adequately to prepare a suitable seedbed with improved physical conditions. The implements used included a chisel plough (Cross plow) to break and loosen the soil and a leveler (scraper) to level the experimental area for the easy movement and uniform distribution of irrigation water.

The Field was then divided into four blocks (Replications) each contained 16 equal plots of $3 \mathrm{~m} \times 2 \mathrm{~m}$ size. Planting was done at first of December 2008 and 2009 for both seasons, respectively; in rows $20 \mathrm{~cm}$ apart at the seed rate of $90 \mathrm{Kg} / \mathrm{h}$ or 48.6 $\mathrm{gm} /$ plot of 11 rows (3m long).

Experimental method is a split-split plot trial with four replications. The main plot was composed of tow methods of fertilizer application in randomized complete block design (RCBD). Subplots consisted of tow types of compound fertilizers. Sub-subplots consisted of four doses of each fertilizer.

The experiment included the following treatments:

\section{A-Application methods of fertilizer (M):}

1- Broadcasting (M1)

2- Localized placement (M2)

B- Fertilizer type ( $T)$ :

1- (Urea $(46 \% \mathrm{~N})+$ Triple super phosphate $(46 \%$ P2O5)) (T1)

2- Nitrophoska (18:18:5) (T2)

C- Fertilizer dose (D):

1- $0 \mathrm{~N}$ and $\mathrm{P}_{2} \mathrm{O}_{5} \mathrm{~kg} / \mathrm{ha} \quad$ (D0)
2- $43 \mathrm{~N}$ and $\mathrm{P}_{2} \mathrm{O}_{5} \mathrm{~kg} / \mathrm{ha}$ (D1)

3- $86 \mathrm{~N}$ and $\mathrm{P}_{2} \mathrm{O}_{5} \mathrm{~kg} / \mathrm{ha}$ (D2)

4- $129 \mathrm{~N}$ and $\mathrm{P}_{2} \mathrm{O}_{5} \mathrm{~kg} / \mathrm{ha} \mathrm{(D3)}$

The seed of wheat cultivar Wadi El Neil (Giza 160) was obtained from Arab Sudanese Seed Company (ASSCO).

Weed control was done by hand weeding ten days after sowing and then as needed throughout the growing season. Irrigations were applied at 7 to 10 days intervals according to temperature range and need of the soil. An insecticide (Morisban 4) was used twice in both seasons to protect the experimental crop from aphids and termites attacks.

Yield components of wheat which were investigated in this study included:

1/ Number of grains/spike: The average numbers of grains per spike were counted from ten randomly selected spikes from the middle five rows of each plot and the average number of grains per spike was calculated.

2/ Thousand grain weight (TGW) (gm): Grain weight in grams was obtained by weighting 1000-grain selected at random from each plot two times.

3/ Spike index: The average spike weight was counted from ten randomly selected spikes from the middle five rows of each plot and the average yield of grains per spike was calculated.

Spike index $=(($ grain yield/spike $)$ spike weight $)$

4/ Grain Yield (t/ha): Plot size was $3 \mathrm{~m} \times 2 \mathrm{~m}$. Plot size consisted of eleven rows $3 \mathrm{~m}$ long; when signs of maturity were clear on the plants (complete yellowing of leaves and spikes) one meter square of the five central rows was harvested for yield. Three outer rows and one meter from both sides of the five inner rows were discarded to eliminate border effects.

Grain yield per plot was converted to grain yield t/ha according to the following formula.

$$
\text { Grain yield }(\mathrm{t} / \mathrm{h})=\text { Grain weight } \mathrm{gm} / \mathrm{plot} / \text { (factor) }
$$

5/ Harvest index (\%): One meter square of the five central rows were cut from the surface of the ground and dried then weighted and the grain yield was recorded.

Harvest index $=(($ grain yield $) /($ biological weight $)) X$
100 
The data collected from the different treatment were subjected to analysis of variance (ANOVA) appropriate for randomized complete block design (Gomez and Gomez, 1984). Duncan's Multiple Range Test (DMRT) was applied for the separation of treatment means. All statistical analyses were performed using M-STAT-C program computer package.

\section{RESULTS AND DISCUSSION}

From the statistical analysis it was clear that there was no significant difference in number of grains per spike between the fertilizer doses in the first season but there were highly significant differences in the second season this result could be due to the residual effect of phosphorus applied at the first season (table 1).

The comparison between the fertilizer doses in the second season (as seen in table 1 and 2) showed that the application of $43 \mathrm{~kg} / \mathrm{ha}$ increased number of grains per spike by $26 \%$ significantly over control, whereas the application of $86 \mathrm{~kg} / \mathrm{ha}$ increased number of grains per spike by $47 \%$ over control. On the other hand, there was no significant difference in the number of grains per spike between the applications of 86 and $129 \mathrm{~kg} / \mathrm{ha}$. This result is supported by the finding of (Ali, 2007) who reported that added fertilizer forms had a highly significant effect on number of grains per spike.

From the results in table (2) it was clear that there was no significant difference in thousand grains weight between the fertilizer doses in both seasons. Similar results were obtained by Ali (1994) who found that no significant effects of nitrogen and phosphorus on thousand grains weight in maize. Also, similar results were found by (Mohammed, 1989) who reported that thousand grain weight was not significantly affected by adding phosphorus fertilizers and (Gill et al; 1970, Vanchev, 1973 and Akasha, 1974) whom founded non significant effect of nitrogen application on thousand grain weight.

The results shows that there was no significant difference in spike index between the fertilizer doses in both seasons (table2), this may due to the increasing in grain and straw yield of spike by fertilizers application.

From the statistical analysis it was clear that there were highly significant differences in grain yield between the fertilizer doses in both seasons. The comparison between the fertilizer doses showed that the highest grain yield obtained by the application of
$129 \mathrm{~kg} / \mathrm{ha}$, and there was no significant difference in the grain yield between the application of 43 and 86 $\mathrm{kg} / \mathrm{ha}$ in the first season. On the other hand, there was no significant difference in the grain yield between the applications of 86 and $129 \mathrm{~kg} / \mathrm{ha}$ in the second season (table 2). The same result was found by (Ali, 2007) who indicated that added fertilizer forms had a highly significant positive effect on grain yield. The same result was found by (Alam et al; 2005).

The results showed that there were highly significant and significant differences in harvest index between the fertilizer doses in both seasons, respectively (table 1).

The comparison between the fertilizer doses showed that the control gave the highest harvest index and the application of $129 \mathrm{~kg} / \mathrm{ha}$ gave the lowest one and this may be due to the increasing in straw yield is more than increasing in grain yield (table 2). This result is supported by many workers; (Net and Dukhuis, 1987) reported that dry matter production during growth and final straw yields were increased by earlier nitrogen application. (Abdel Rahman, 1997) showed that addition of phosphorous significantly increased wheat straw yield.

It was clear that there were no significant differences between the fertilizer types in Yield and yield components in both seasons (table 3 ). The similar results were found by (Ali, 2007) who reported that differences in these traits among the different added fertilizer types were not significant.

In both seasons the effects of application methods in yield parameters were not significant (table 4). These results might be due to the control in fertilizers distribution under experimental conditions. Similar result was found by (Ibrahim, et al; 1991) who reported that there were no significant differences between the different methods of phosphorus application.

From the results of this study it can be concluded that:

1- Grain yield significantly positive increased with fertilizers doses but there was no significant difference between 86 and 129 $\mathrm{kg} / \mathrm{ha}$.

There were no significant differences between fertilizer types on grain yield of wheat. Also, there were no significant differences between the application methods of fertilizer. 
Agric. Biol. J. N. Am., 2012, 3(3):125-130

Table (1): F- value of the measured variables for the different fertilizer type (T), application (M) and doses (D) during (2008/2009 and 2009/2010) seasons.

\begin{tabular}{|c|c|c|c|c|c|c|c|c|c|c|}
\hline \multirow{2}{*}{ Treatment } & \multicolumn{2}{|c|}{ No. of grains/spike } & \multicolumn{2}{|c|}{ TGW } & \multicolumn{2}{|c|}{ Spike index } & \multicolumn{2}{|c|}{ Yield t/ha } & \multicolumn{2}{|c|}{ Harvest index } \\
\hline & $1^{\text {st }}$ Season & $2^{\text {nd }}$ Season & $1^{\text {st }}$ Season & $2^{\text {nd }}$ Season & $1^{\text {st }}$ Season & $2^{\text {nd }}$ Season & $1^{\text {st }}$ Season & $2^{\text {nd }}$ Season & $1^{\text {st }}$ Season & $2^{\text {nd }}$ Season \\
\hline$M$ & $1.54^{n . s}$ & $1.30^{n . s}$ & $1.10^{\text {n.s }}$ & $5.30^{n . s}$ & $0.42^{n . s}$ & $0.61^{\text {n.s }}$ & $1.20^{\mathrm{n} . \mathrm{s}}$ & $0.12^{n . s}$ & $0.04^{n . s}$ & $2.92^{n . s}$ \\
\hline $\mathrm{T}$ & $0.55^{n . s}$ & $0.02^{n . s}$ & $0.97^{n . s}$ & $0.35^{n . s}$ & $0.61^{n . s}$ & $4.47^{\mathrm{n} . \mathrm{s}}$ & $0.79^{n . s}$ & $0.43^{n . s}$ & $0.24^{n . s}$ & $2.77^{\mathrm{n} . \mathrm{s}}$ \\
\hline$D$ & $1.99^{\mathrm{n} . \mathrm{s}}$ & $27.12^{\star *}$ & $2.36^{\mathrm{n} . \mathrm{s}}$ & $0.56^{\mathrm{n} . \mathrm{s}}$ & $0.83^{n . s}$ & $2.85^{\mathrm{n} . \mathrm{s}}$ & $19.14^{* *}$ & $30.34^{\star *}$ & $11.63^{* *}$ & $3.11^{*}$ \\
\hline
\end{tabular}

$=$ significant at $1 \%$ level (highly significant)

n.s = not significant

Table (2): Effect of fertilizer dose on yield and yield components of wheat along with their significance ranking in (2008/09 and 2009/10 seasons)

\begin{tabular}{|c|c|c|c|c|c|c|c|c|c|c|}
\hline \multirow{2}{*}{ Treatments } & \multicolumn{2}{|c|}{ No. of grains/spike } & \multicolumn{2}{|c|}{ Thousand grain weight } & \multicolumn{2}{|c|}{ Spike index } & \multicolumn{2}{|c|}{ Yield (t/ha) } & \multicolumn{2}{|c|}{ Harvest index } \\
\hline & $1^{\text {st }}$ season & $2^{\text {nd }}$ season & $1^{\text {st }}$ season & $2^{\text {nd }}$ season & $1^{\text {st }}$ season & $2^{\text {nd }}$ season & $1^{\text {st }}$ season & $2^{\text {nd }}$ season & $1^{\text {st }}$ season & $2^{\text {nd }}$ season \\
\hline D0 & $36.58 a$ & $24.93 \mathrm{c}$ & $40.17 a$ & $36.07 a$ & $69.54 a$ & $70.28 a$ & $2.32 \mathrm{c}$ & $0.81 \mathrm{c}$ & $40.43 a$ & $30.60 a$ \\
\hline D1 & $38.62 a$ & $31.38 b$ & $39.34 a$ & $35.62 a$ & $69.27 a$ & $69.34 a$ & $3.22 b$ & $1.72 b$ & $36.43 b$ & $26.70 \mathrm{~b}$ \\
\hline $\mathrm{D} 2$ & $39.06 a$ & $36.69 a$ & $41.29 a$ & $34.94 a$ & $70.29 a$ & $67.94 a$ & $3.75 b$ & $2.44 a$ & $36.51 b$ & $29.37 a b$ \\
\hline D3 & $39.13 a$ & $37.67 a$ & $40.15 a$ & $35.35 a$ & $69.10 a$ & $68.97 a$ & $4.67 a$ & $2.64 a$ & $34.94 b$ & $30.18 a$ \\
\hline LSD & 2.439 & 3.223 & 1.501 & 1.827 & 1.652 & 1.646 & 0.6461 & 0.4332 & 1.974 & 2.847 \\
\hline SE \pm & 0.851 & 1.124 & 0.523 & 0.6369 & 0.576 & 0.5739 & 0.225 & 0.151 & 0.6882 & 0.9926 \\
\hline CV\% & 8.87 & 13.76 & 5.20 & 7.18 & 3.31 & 3.32 & 25.81 & 31.37 & 7.42 & 13.59 \\
\hline
\end{tabular}

Means within column followed by the same letter(s) were not significantly different according to Duncan's Multiple Range test at $5 \%$ level. 
Agric. Biol. J. N. Am., 2012, 3(3):125-130

Table (3): Effect of fertilizer type on yield and yield components of wheat along with their significance ranking in (2008/09 and 2009/10 seasons)

\begin{tabular}{|c|c|c|c|c|c|c|c|c|c|c|}
\hline \multirow{2}{*}{ Treatments } & \multicolumn{2}{|c|}{ No. of grains/spike } & \multicolumn{2}{|c|}{ Thousand grain weight } & \multicolumn{2}{|c|}{ Spike index } & \multicolumn{2}{|c|}{ Yield (t/ha) } & \multicolumn{2}{|c|}{ Harvest index } \\
\hline & $1^{\text {st }}$ season & $2^{\text {nd }}$ season & $1^{\text {st }}$ season & $2^{\text {nd }}$ season & $1^{\text {st }}$ season & $2^{\text {nd }}$ season & $1^{\text {st }}$ season & $2^{\text {nd }}$ season & $1^{\text {st }}$ season & $2^{\text {nd }}$ season \\
\hline T1 & $38.88 a$ & $32.76 a$ & $40.66 a$ & $35.62 a$ & $69.93 a$ & $69.72 a$ & $3.30 a$ & $1.94 a$ & $37.25 a$ & $30.67 a$ \\
\hline T2 & $37.81 a$ & $32.57 a$ & $39.82 a$ & $35.36 a$ & $69.17 a$ & $68.55 a$ & $3.68 a$ & $1.87 \mathrm{a}$ & $36.91 a$ & $27.76 a$ \\
\hline LSD & 3.54 & 2.98 & 2.09 & 1.09 & 2.37 & 1.36 & 1.06 & 0.27 & 1.71 & 4.29 \\
\hline SE \pm & 1.0206 & 0.8601 & 0.6037 & 0.3137 & 0.6833 & 0.3914 & 0.3055 & 0.0795 & 0.4930 & 1.2375 \\
\hline CV\% & 8.87 & 13.76 & 5.20 & 7.18 & 3.31 & 3.32 & 25.81 & 31.37 & 7.42 & 13.59 \\
\hline
\end{tabular}

Means within column followed by the same letter(s) were not significantly different according to Duncan's Multiple Range test at $5 \%$ level.

Table (4): Effect of fertilizer method on yield and yield components of wheat along with their significance ranking in (2008/09 and 2009/10 seasons)

\begin{tabular}{|c|c|c|c|c|c|c|c|c|c|c|}
\hline \multirow{2}{*}{ Treatments } & \multicolumn{2}{|c|}{ No. of grains/spike } & \multicolumn{2}{|c|}{ Thousand grain weight } & \multicolumn{2}{|c|}{ Spike index } & \multicolumn{2}{|c|}{ Yield (t/ha) } & \multicolumn{2}{|c|}{ Harvest index } \\
\hline & $1^{\text {st }}$ season & $2^{\text {nd }}$ season & $1^{\text {st }}$ season & $2^{\text {nd }}$ season & $1^{\text {st }}$ season & $2^{\text {nd }}$ season & $1^{\text {st }}$ season & $2^{\text {nd }}$ season & $1^{\text {st }}$ season & $2^{\text {nd }}$ season \\
\hline M1 & $39.29 a$ & $31.98 a$ & $40.85 a$ & $35.95 a$ & $69.91 \mathrm{a}$ & $69.33 a$ & $3.60 \mathrm{a}$ & $1.86 \mathrm{a}$ & $37.11 \mathrm{a}$ & $29.89 a$ \\
\hline M2 & $37.41 \mathrm{a}$ & $33.36 a$ & $39.62 a$ & $35.04 a$ & $69.20 \mathrm{a}$ & $68.94 a$ & $3.39 a$ & $1.95 \mathrm{a}$ & $37.04 a$ & $28.53 a$ \\
\hline LSD & 4.81 & 3.84 & 3.73 & 1.25 & 3.50 & 1.58 & 0.61 & 0.86 & 1.18 & 2.54 \\
\hline SE \pm & 1.0703 & 0.8544 & 0.8287 & 0.2791 & 0.7790 & 0.3505 & 0.1356 & 0.1911 & 0.2630 & 0.5643 \\
\hline CV\% & 8.87 & 13.76 & 5.20 & 7.18 & 3.31 & 3.32 & 25.81 & 31.37 & 7.42 & 13.59 \\
\hline
\end{tabular}

Means within column followed by the same letter(s) were not significantly different according to Duncan's Multiple Range test at $5 \%$ level. 


\section{REFERENCES:}

Abdel Rahman, F. M.A. 1997. The effect of phosphorus and time of nitrogen application on growth and yield of wheat (Triticum aestivum L.). MSc. Thesis. U of K, Sudan.

Alam, S.M., Shah, S.A. and Iqbal, M.M. 2005. Evaluation of method and time of fertilizer application for yield and optimum P-efficiency in wheat Songklanakarin J. Sci. Technol., 27(3) : 457-463

Ageeb, O. A. A. 1993. Agronomic aspect of wheat production in Sudan. In (Wheat in Heat-Stressed Environments: Irrigated, Dry Areas and Rice Wheat Farming Systems) (ed./ D. A. Saunders and G. P. Hettel) pp. 154-162.

Akasha, M. H. 1974. Wheat phosphorus experiment. Annual Rep. of Gezira Res. Station and Substation, Sudan. Season 1973-74. pp 30.

Ali, A, A, 2007. Effect of different fertilizer forms on wheat yield and grain quality in the Gezira M. Sc. Thesis in Plant nutrition. Sudan Academy of Sciences, Khartoum (Sudan).

Ali, F. M. (1994) Annual report. Maize research program. Ministry of agricultural and forestry. sudan

Dawelbeit, S. E., Salih, F. M., Dahab, O. A. and Ahmid, S. E. H., (2007). Current Research in Fertilizer use in Irrigated Agriculture in Sudan. 13th AFA Int'l Annual Fertilizers Forum \& Exhibition 6-8 February 2007 Intercontinental Hotel- Sharm El-Sheikh, Egypt

FAO, 2001. Special Report. Crop and food supply situation in Sudan. FAO Global Information and early warning system on Food and Agriculture. Food and Agriculture Organization of the United Nation, Rome 2001.

Gill, G. S., Batra, P. C. and Rondhawa, N. S. (1970). Rwsponse of two gene dwarf wheat to split application on N. Indian J. Agron. 15(4): 369-372.

Gomez, K. A and Gomez, A. A. 1984. Randomized Complete Block Design Analysis In: Statistical procedures for Agricultural Research. John Willy and Sons, New York.

Ibrahim, H. S., Babiker, E. A., Mohamed, G. E., Omer, M. M. Gorashi, A. M., Salih, A. A., Satti, E. and Mohamed, M. I. 1991. Response of wheat to different rates of NP combinations and the method of $P$ application in the Sudan. Pages 60-70 in Nile Valley Regional Program. Bread wheat report - Sudan, Annual coordination meeting, 16 - 23 September 1991, Cairo, Egypt.

Mohamed, G. E., 1989. Wheat varietal response to $\mathrm{N}$ under two different soil types in Shendi area. Annual National Wheat Coordination Meeting, 4-7 September 1989, Agricultural research corporation, Wad Medani, Sudan.

Net, A. A.; Dukhuis, F. J. 1990. Effect of seeding rate, time of $\mathrm{N}$ application and frequency of irrigation water on wheat growth, yield and water use. South Africa Journal of Plant and Soil 7 (3): 163-166

Vanchev, N. 1973. Effect of date of application of ammonium nitrate to wheat grown in South Bulgaria. Field crop abstract. 16 (2): 54. 